\title{
Kolaborasi Alat Musik Tradisional dan Alat Musik Modern dalam Mengiringi Ibadah Minggu di Huria Kristen Batak Protestan Tanjung Sari Medan
} Bella Cindy Juwita Simanjuntak, Pulumun Peterus Ginting \& Wiflihani*

\author{
Jurusan Sendratasik, Fakultas Bahasa dan Seni, Universitas Negeri Medan, Indonesia
}

Diterima: Februari 2019; Disetujui: Maret 2019; Dipublish: April 2019

*E-mail: wiflihani@unimed.ac.id

\begin{abstract}
Abstrak
Penelitian ini membahas tentang kolaborasi alat musik tradisional dan alat musik modern dalam mengiringi Ibadah Minggu di HKBP Tanjung Sari Medan. Tujuan penelitian ini untuk mengetahui latar belakang dan proses kolaborasi alat musik tradisional dan alat musik modern di gereja HKBP Tanjung Sari Medan. Metode yang digunakan dalam penelitian ini adalah deskriptif kualitatif. Lokasi penelitian dilakukan di gereja HKBP Tanjung Sari, Jl. Setia Budi No. 11, Medan. Populasi penelitian ini adalah alat musik tradisional dan alat musik modern yang digunakan dalam mengiringi Ibadah Minggu di HKBP Tanjung Sari Medan. Sedangkan Sampel dalam penelitian ini adalah Taganing, drum, keyboard, gitar akustik, gitar bass, saxophone yang digunakan mengiringi Ibadah Minggu di HKBP Tanjung Sari Medan. Teknik pengumpulan datanya melalui observasi, wawancara, dokumentasi, dan studi kepustakaan. Berdasarkan hasil penelitian, dapat diketahui bahwa alat musik tradisional dan alat musik modern yang digunakan dalam mengiringi Ibadah Minggu di HKBP Tanjung Sari Medan, yaitu: Taganing, drum, keyboard, gitar akustik, gitar bass, saxophone. Lagu-lagu yang digunakan dalam mengiringi Ibadah Minggu di HKBP Tanjung Sari Medan, dan proses kolaborasi alat musik tradisional dan alat musik modern di gereja HKBP Tanjung Sari Medan.
\end{abstract}

Kata Kunci: Kolaborasi, Alat Musik Tradisional, Alat Musik Modern, Ibadah Minggu.

\begin{abstract}
This study discusses the collaboration of traditional musical instruments and modern musical instruments in accompanying Sunday services at HKBP Tanjung Sari Medan. The purpose of this study was to find out the background and process of collaboration of traditional musical instruments and modern musical instruments in the HKBP Tanjung Sari church in Medan. The method used in this study is qualitative descriptive. The location of the study was carried out at the Tanjung Sari HKBP church, Jl. Setia Budi No. 11, Medan. The population of this study is traditional musical instruments and modern musical instruments used in accompanying Sunday services at HKBP Tanjung Sari Medan. While the samples in this study were Taganing, drums, keyboards, acoustic guitars, bass guitars, saxophone which were used to accompany Sunday services at HKBP Tanjung Sari Medan. The data collection technique is through observation, interviews, documentation, and library studies. Based on the results of the study, it can be seen that traditional musical instruments and modern musical instruments used in accompanying Sunday services at HKBP Tanjung Sari Medan, namely: Taganing, drums, keyboards, acoustic guitars, bass guitars, saxophone. The songs used in accompanying Sunday Service at HKBP Tanjung Sari Medan, and the collaboration process of traditional musical instruments and modern musical instruments in the HKBP Tanjung Sari church in Medan.

Keywords: Collaboration, Traditional Musical Instruments and Modern Musical Instruments, Worship
\end{abstract}

How to Cite: Simanjuntak, B.C.J. Ginting, P.P \& Wiflihani (2019). Kolaborasi Alat Musik Tradisional dan Alat Musik Modern dalam Mengiringi Ibadah Minggu di HKBP Tanjung Sari Medan. Journal of Education, Humaniora and Social Sciences (JEHSS). 1 (3): 169-176. 


\section{PENDAHULUAN}

Masyarakat Indonesia merupakan suatu masyarakat majemuk yang terdiri dari berbagai suku bangsa, agama, bahasa, budaya. Kemajemukan bangsa yang terbangun dari perbedaan kebudayaan dan sejarah atau cikal bakal lahirnya kebudayaan itu sendiri memiliki pengalaman dan perkembangan sejarahnya berbeda-beda dari satu suku dengan suku yang lain.

Perkembangan musik dunia makin lama perkembang kian pesat, khususnya di Indonesia musik pada era saat ini telah berbeda dengan musik pada masa Indonesia di tahun lalu. Pada saat ini, alat musik tradisional seperti suling, hasapi, gendang dan alat musik tradisional lainnya, kurang diminati anak- anak dan remaja, karena saat ini anak-anak dan remaja lebih menggemari alat musik modern seperti gitar listrik, saxophone, biola dan alat musik modern lainnya.

Pada hakikatnya musik daerah adalah musik yang tumbuh dan berkembang di nusantara, tetapi pada saat ini musik-musik tersebut tidak terlalu menarik perhatian peminat musik dan kurangnya sarana sebagai tempat untuk mengembangkan musik daerah tersebut (Fathoni, 2012).

Kebudayaan merupakan bagian dari kehidupan masyarakat, dimana kebudayaan dan masyarakat tidak dapat dipisahkan, karena di dalam kehidupan manusia selalu mencipta dan menggunakan kebudayaan untuk memenuhi kebutuhan. Kebudayaan daerah terangkum di dalam kebudayaan nasional. Salah satu dari sekian banyak kebudayaan tersebut adalah kebudayaan suku Batak.

Suku Batak terdiri atas enam sub suku yaitu Toba, Karo, Simalungun, Pakpak, Angkola dan Mandailing. Sebagian besar suku Batak masih memelihara kebudayaan yang diwariskan oleh nenek moyang. Etnis Batak Toba memiliki budaya yang diwariskan turun-temurun oleh nenek moyang secara lisan.

Salah satu warisan dari kebudayaan tersebut adalah kesenian. Kesenian pada suku Batak Toba sangat banyak, di antaranya adalah seni tenun, seni tari, seni ukir, seni patung dan seni musik. Aktivitas musikal yang digunakan dalam setiap upacara adat dan ritual keagamaan suku Batak Toba dikenal dengan sebutan Gondang. Dalam bahasa Batak Toba, katadang mengandung banyak pengertian, di antaranya adalah instrumen musikal, ansambel musik, judul sebuah komposisi musik, judul kolektif dari beberapa komposisi musik (repertoar), tempo pada komposisi, suatu rangkaian upacara, menunjukkan suatu kelompok misalnya kelompok kekerabatan atau pun tingkat usia, dan bisa juga berarti sebuah doa (Hutajulu dan Harahap, 2005).

Bagi suku Batak Toba, Gondang memiliki peranan yang sangat penting. Dapat dikatakan bahwa tidak ada sebuah bentuk upacara pun yang tidak melibatkan Gondang, baik itu upacara adat maupun ritual keagamaan. Hal ini dapat dilihat dalam sebuah falsafi tradisional masyarakat Batak Toba yang menyatakan bahwa Gondang merupakan "alat utama" untuk mencapai hubungan antara manusia dan sang pencipta segalanya (Tuhan pada suku Batak Toba) yang disebut "Debata Mulajadi Na Bolon". Konteks ini merupakan sebuah ritual keagamaan dimana Gondang digunakan sebagai sarana komunikasi antara manusia terhadap sang pencipta, sehingga setiap musik yang dihadirkan atau dimainkan memiliki makna sebagai persembahan, pujian dan doa (Hutajulu dan Harahap, 2005).

Taganing adalah salah satu instrument pukul dari sekian banyak instrument pukul tradisonal Batak Toba. Taganing merupakan seperangkat gendang bersisi satu (single-headed braced drum) yang berasal dari kebudayaan Batak Toba. Alat musik ini terdiri dari lima buah drum dengan nada yang masing-masing berbeda, yakni odap-odap (gendang yang paling besar/lebih kecil dari gordang), paidua odap-odap, painonga, paidua ting ting, dan ting ting (gendang yang paling kecil). Alat ini dimainkan oleh satu orang yang disebut partaganing dengan menggunakan dua buah stik pemukul (palu-palu).

Tidak jarang di berbagai pesta adat dan ritual keagamaan Batak Toba, apa yang dikenal dengan musik keyboard, yang kadang kala digabungkan dengan saxophone di kalangan suku Batak Toba, di samping musik brass band dengan gaya lokal selalu menjadi pilihan. Sementara itu musik tradisionalnya terpinggirkan karena telah menjadi asing di pendengaran mereka; bahkan 触http://mahesainstitute.web.id/ojs2/index.php/jehss 
sebagian mengatakan kuno, sebab terlalu banyak aturan adat yang harus dijalankan untuk menghadirkannya.

Faktor lain yang menyebabkan berkurangnya perhatian masyarakat terhadap musik tradisional Gondang adalah masyarakat mulai melupakan sejarah musik tradisional Gondang itu sendiri. Masyarakat sebenarnya mempunyai peranan penting dalam mengembangkan dan melestarikan seni musik tradisional serta menjadikan musik tradisional sebagai pembendaharaan seni.

Musik gereja dalam suku Batak Toba tidak terlepas dari datangnya missionaris ke daerah Batak Toba untuk memberitakan injil ke Tanah Batak. Di samping memberitakan injil, para missionaris juga mulai memperkenalkan instrumen musik dan mengajarkan nyanyian yang berasal dari nyanyian-nyanyian gereja yang ada di Eropa (Yusuf, 2017),

Nyanyian-nyanyian dalam buku ende HKBP sebagai sumber nyanyian dalam setiap ibadah yang dilakukan oleh gereja HKBP kurang lebih sudah berlangsung selama 143 tahun tanpa ada penambahan lagu-lagu baru. Pada tahun 2003, berdasarkan masukan dari jemaat dan juga melihat perkembangan jaman, otoritas HKBP membentuk Tim untuk menyusun lagu-lagu baru sebagai nyayian tambahan dari nyanyian Buku Ende. Tahun 2004, melalui Rapat Parhalado HKBP mensyahkan penggunaan lagu-lagu baru (Buku Ende Suplemen) dalam ibadah-ibadah yang dilakukan oleh gereja HKBP.

Ada beberapa penelitian yang pernah dilakukan, misalnya, Nixon Manurung "Bentuk dan Fungsi Musik Gondang Sabangunan Batak Toba Pada Grup Horas Rapolo Musik di Semarang" Dalam penulisan ini dipaparkan bahwa di samping mengenalkan musik tradisional, keberadaan Horas Rapolo Musik merupakan ritual adat yang tidak bertentangan dengan ajaran agama lain, yang mana Gondang berfungsi sebagai sarana upacara seperti dalam upacara adat, pesta pembangunan gereja, pesta muda-mudi, pesta marga-marga, pesta perkawinan, upacara orang tua meninggal dunia, dan dapat pula sebagai sarana untuk mengungkapkan rasa kegembiraan dan sebagai tontonan atau hiburan khususnya bagi suku Batak Toba yang sebagian besar memeluk agama Kristen.

Tambunan (2017) dan Silitonga (2017), mengatakan bahwa adat Batak sama seperti semua seni budaya tradisional etnis lainnya dapat dimanfaatkan sebagai media pendidikan bagi proses ibadah dalam komunitas jemaat. Adat dan budaya tradisional batak dengan berbagai macam ekspresinya akan dilihat sebagai nilai-nilai kristiani. Dengan demikian seni budaya tradisional batak dapat dipakai menjadi makna dalam komunitas Kristen. Dalam tatanan ibadah HKBP yang secara khusus merupakan gereja suku dan lebih spesifik lagi mayoritas jemaatnya merupakan suku batak toba sudah seharusnya memiliki suatu ansamble Gondang dalam ibadahnya.

Ada banyak alat musik modern yang bisa dikolaborasikan dengan instrumen musik tradisional seperti suling, Gondang, hasapi/kecapi dan masih banyak lagi alat musik yang dapat dikolaborasikan untuk perkembangan iringan musik di gereja. Fenomena masuknya Alat musik tradisional ke dalam acara peribadatan ini terjadi di HKBP Ressort Tanjung Sari Medan. Atas dasar inilah penulis tertarik untuk melakukan penelitian mengenai pengkolaborasian alat musik tradisional dan alat musik modern dalam mengiringi ibadah.

\section{METODE PENELITIAN}

Sesuai dengan permasalahan yang dikaji dalam tulisan ini, penelitian ini menggunakan pendekatan deskriptif kualitatif. Penelitian deskriptif mengumpulkan data, menentukan dan melaporkan yang ada menurut kenyataan. Sifat kualitatif penelitian akan mengarah pada mutu dan kedalaman uraian, yakni pembahasan tentang Kolaborasi alat musik tradisional dan alat musik modern di gereja HKBP Tanjung Sari Medan.

Pendekatan kualitatif memusatkan perhatian pada prinsip umum yang mendekati perwujudan suatu gejala-gejala yang ada dalam kehidupan manusia atas pola-pola. Penelitian dengan pendekatan kualitatif memungkinkan untuk memahami masyarakat secara personal atau memandang mereka secara umum, mereka sendiri mengungkapkan secara alami.

Metode mempunyai peranan yang sangat penting. Metode merupakan syarat atau langkahlangkah yang dilakukan dalam suatu penelitian. Hal ini sangat perlu agar tujuan penelitian yang 
diharapkan dapat tercapai, maka metode yang digunakan harus sangat jelas. Hal tersebut di atas sesuai dengan pendapat Sugiono (2009) yang mengatakan bahwa "secara umum metode penelitian diartikan sebagai cara ilmiah untuk mendapatkan data dengan tujuan dan kegunaan tertentu".

Populasi dalam penelitian merupakan hal yang sangat penting untuk menentukan beberapa jumlah populasi sesuai dengan data yang akan dikumpulkan. Menurut Sugiono (2008) mengatakan bahwa "Populasi adalah wilayah generalisasi yang terdiri atas objek/subjek yang mempunyai kualitas dan karakteristik tertentu yang diterapkan oleh peneliti untuk dipelajari dan kemudian ditarik kesimpulannya". Berdasarkan pendapat di atas maka populasi dari penelitian ini adalah 4 orang Pendeta HKBP Tanjung Sari Medan, 15 orang Pemusik dan 150 jemaat HKBP Tanjung Sari Medan.

Menurut Sugiyono (2008), yang menyatakan bahwa "Sampel adalah bagian dari jumlah dan karakteristik yang dimiliki oleh populasi". Sampel yang diambil pada penelitian ini adalah 1 orang Pendeta Ressort HKBP Tanjung Sari Medan, 2 Pemusik dan 5 perwakilan jemaat HKBP. Menurut Sugiyono (2008) "Teknik pengumpulan data merupakan langkah yang paling utama dalam penelitian, karena tujuan utama dalam penelitian adalah mendapatkan data. Tanpa mengetahui dan menjalankan teknik pengumpulan data yang tepat, maka peneliti tidak akan mendapat data yang memenuhi standar yang diterapkan".

Adapun teknik pengumpulan data yang digunakan dalam penelitian ini dilakukan dengan cara: Observasi disebut juga pengamatan, pemusatan perhatian terhadap suatu objek yang menggunakan saluran pancaindra (Arikunto, 2010). Bungin (2007) mengatakan bahwa, "observasi adalah kegiatan keseharian manusia dengan menggunakan panca indra mata sebagai alat bantu utamanya selain panca indra lainnya seperti telinga, penciuman, mulut dan kulit". Observasi atau pengamatan, dapat berarti setiap kegiatan untuk melakukan pengukuran dengan menggunakan indra penglihatan.

Metode observasi atau pengamatan meliputi kegiatan pemusatan perhatian terhadap sesuatu objek dengan menggunakan seluruh alat indera. Penulis lebih banyak mengamati objek penelitian secara langsung dalam ritual ibadah di HKBP Tanjung Sari Medan. Penulis juga banyak tinggal di antara pionir-pionir budaya yaitu pelatih Gondang di HKBP Tanjung Sari Medan, kemudian memperhatikan pengalaman mereka dalam proses Kolaborasi. Dalam penelitian ini dilakukan pengamatan tentang alat musik tradisional dan alat musik modern yang dipakai dalam mengiringi ibadah minggu di HKBP Tanjung Sari Medan.

Salah satu teknik pengumpulan data adalah wawancara. Wawancara yaitu percakapan dengan maksud tertentu dimana di dalamnya dilakukan oleh dua pihak, yaitu pewawancara (interviewer) yang mengajukan pertanyaan dan yang diwawancarai (interview) yang memberikan jawaban atas pertanyaan. Teknik wawancara yang dilakukan penulis adalah wawancara berfokus (focused interview) dan wawancara bebas (free interview). Sebelum melakukan wawancara penulis terlebih dahulu menentukan pada siapa wawancara akan dilakukan, kemudian melakukan wawancara yang hasilnya ditulis dalam catatan lapangan.

Informan dalam wawancara ini yaitu Pendeta Ressort HKBP Tanjung Sari Medan, Pemusik dan beberapa perwakilan jemaat HKBP. Pada wawancara berfokus, pertanyaan berpusat kepada pokok permasalahan, sedangkan pada wawancara bebas pertanyaan tidak berpusat pada permasalahan tetapi beralih pada permasalahan yang lain untuk memperoleh data yang beraneka ragam.

Dengan wawancara, informasi yang diperoleh berupa data-data yang diharapkan atau hasil yang diperoleh akurat dan terpercaya serta dapat memperluas informasi yang dibutuhkan dalam penelitian. Dokumentasi adalah teknik pengumpulan data yang berhubungan dengan dokumen baik dalam bentuk laporan, surat-surat resmi maupun catatan harian dan sebagainya. Penulis juga menggunakan berbagai macam dokumentasi pada saat di lapangan diantaranya video, fotofoto, arsip-arsip.

Hal ini bertujuan agar dokumen tersebut diharapkan dapat memberikan uraian dan wujud tentang kolaborasi alat musik tradisional dan alat musik modern di HKBP Tanjung Sari Wwh http://mahesainstitute.web.id/ojs2/index.php/jehss

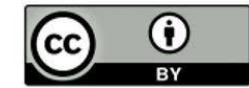


Medan. Proses penelitian di HKBP Tanjung Sari Medan juga akan dilakukan perekaman hasil wawancara dengan pihak gereja HKBP Tanjung Sari untuk dapat diolah secara detail tanpa mengubah makna yang terkandung di dalamnya.

Dokumentasi digunakan untuk memperluas penelitian, karena alasan-alasan yang dapat dipertanggungjawabkan. Dokumentasi ini diharapkan dapat membantu peneliti mempelajari dokumen yang berhubungan dengan materi kolaborasi alat musik tradisional dan alat musik modern di HKBP Tanjung Sari Medan.

\section{HASIL DAN PEMBAHASAN}

\section{Alat Musik Pengiring Ibadah}

Taganing adalah salah satu alat musik Batak Toba, yang terdiri lima buah gendang yang berfungsi sebagai pembawa melodi dan juga sebagai ritem variable dalam beberapa lagu. Menurut salah satu pemusik yaitu Mr. Mareza proses kolaborasi alat musik tradisional taganing ini dengan alat musik modern sering digunakan saat ibadah pagi, dikarenakan jadwal pemusik yang tidak hanya mengiringi di satu gereja saja, karena itu pemusik menyepakati untuk menggunakan kolaborasi alat musik tradisional dengan alat musik modern pada saat ibadah pagi, akan tetapi tidak menutup kemungkinan juga pemusik menggunakan kolaborasi alat musik tradisional dengan alat musik modern pada saat ibadah siang dan sore.

Pemilihan lagu tergantung kepada kesepakatan seluruh pemusiknya, lagu yang digunakan ketika memakai alat musik taganing ini lebih sering menggunakan lagu terdapat pada buku ende seperti Marolop-olop, Dung Tuhan Jesus dan sebagainya. Alat musik tradisional ini dikolaborasikan dengan alat musik modern biasanya pada saat membuka ibadah dan ketika pengumpulan kolekte I-IV.

Kedua adalah Keyboard dan Organ, yang menurut Mr. Mareza salah satu pemusik di Gereja HKBP Tanjung Sari Medan, alat musik digunakan pada ibadah minggu baik ibadah minggu pagi, ibadah minggu siang dan juga ibadah minggu sore. Keyboard untuk memainkan akord dan organ memainkan melodi. Pemilihan lagu juga tergantung kepada kesepakatan seluruh pemusiknya, lagu yang digunakan ketika memakai alat musik saxophone ini menggunakan lagu yang terdapat pada buku kidung jemaat seperti lagu Ku Heran Allah Mau Memb'ri, buku ende seperti lagu Marolop-olop, dan lagu Pop Religi seperti lagu Arti Kehadiranmu. Alat musik modern saxophone digunakan pada setiap lagu baik pada saat membuka ibadah hingga akhir ibadah.

Alat musik ketiga adalah drum set, yng menurut Mr. Mareza, alat musik drum digunakan pada ibadah minggu baik ibadah minggu pagi, ibadah minggu siang dan juga ibadah minggu sore. Drum oleh pemusik dapat juga dikolaborasikan dengan taganing. Pemilihan lagu juga tergantung kepada kesepakatan seluruh pemusiknya, lagu yang digunakan ketika memakai alat musik saxophone ini menggunakan lagu yang terdapat pada buku kidung jemaat seperti lagu $\mathrm{Ku}$ Heran Allah Mau Memberi, buku ende seperti lagu Marolop-olop, dan lagu Pop Religi seperti lagu Arti Kehadiranmu. Alat musik modern saxophone digunakan pada setiap lagu baik pada saat membuka ibadah hingga akhir ibadah.

Alat music keempat adalah gitar akustik, yang menurut Mr. Mareza, alat musik gitar ini digunakan pada ibadah minggu baik ibadah minggu pagi, ibadah minggu siang dan juga ibadah minggu sore. Gitar akustik oleh pemusik dapat dibunyikan seperti hasapi. Pemilihan lagu juga tergantung kepada kesepakatan seluruh pemusiknya, lagu yang digunakan ketika memakai alat musik saxophone ini menggunakan lagu yang terdapat pada buku Kidung Jemaat seperti lagu Ku Heran Allah Mau Memberi, buku ende seperti lagu Marolop-olop, dan lagu Pop Religi seperti lagu Arti Kehadiranmu. Alat musik modern ini digunakan pada setiap lagu baik pada saat membuka ibadah hingga akhir ibadah.

Keempat adalah, alat music gitar bass, yang menurut Mr. Mareza, sama halnya dengan alatmusik gitar akustik, alat musik gitar bass ini digunakan pada ibadah minggu baik ibadah 
minggu pagi, ibadah minggu siang dan juga ibadah minggu sore. Pemilihan lagu juga tergantung kepada kesepakatan seluruh pemusiknya, lagu yang digunakan ketika memakai alat musik saxophone ini menggunakan lagu yang terdapat pada buku kidung jemaat seperti lagu $\mathrm{Ku}$ Heran Allah Mau Memberi, buku ende seperti lagu Marolop-olop, dan lagu Pop Religi seperti lagu Arti Kehadiranmu. Alat musik modernini digunakan pada setiap lagu baik pada saat membuka ibadah hingga akhir ibadah.

Kelima adalah saxophone, yang digunakan pada ibadah minggu baik ibadah minggu pagi, ibadah minggu siang dan juga ibadah minggu sore. Akan tetapi, tidak setiap minggu alat musik saxophone ini bisa jemaat nikmati dikarenakan pemusik tidak hanya mengiringi di satu gereja saja dan tidak pada waktu yang sama. Pemilihan lagu juga tergantung kepada kesepakatan seluruh pemusiknya, lagu yang digunakan ketika memakai alat musik saxophone ini menggunakan lagu yang terdapat pada buku kidung jemaat seperti lagu Ku Heran Allah Mau Memberi, buku ende seperti lagu Marolop-olop, dan lagu Pop Religi seperti lagu Arti Kehadiranmu. Alat musik modern saxofon digunakan pada setiap lagu baik pada saat membuka ibadah hingga akhir ibadah.

Personil alat musik tradisional dan alat musik modern dan song leader didominasi oleh pemuda/i gereja. Wawancara yang dilakukan penulis dengan tim musik ditemukan bahwa hampir seluruhnya mereka tidak mempunya basic musik yang didapat melalui institusi musik formal. Sebahagian dari mereka memperoleh pengetahuan musik dari aktivitas privat musik dan sebagian lagi memperoleh pengetahuan musik belajar otodidak.

\section{Proses Kolaborasi Alat Musik Tradisional dan Alat Musik Modern}

Kebaktian minggu adalah ibadah yang dilaksanakan di gereja setiap hari Minggu merupakan suatu persekutuan hidup dengan Tuhan dan juga sesama anggota jemaat lainnya. Kebaktian minggu merupakan suatu pertemuan yang terbuka, dimana umat Kristen berkumpul bersekutu kepada Tuhan dengan sesama manusia.

Sesuai dengan hasil wawancara dengan salah satu anggota pemusik di HKBP Tanjung Sari Medan yaitu Mareza bahwa latihan untuk pemusik dimulai setiap hari Sabtu, pada pukul 19.30 WIB dilaksanakan di gereja dan atau di gedung serbaguna. Pemusik latihan menggunakan Buku ende dan juga Kidung Jemaat, dan tak jarang pemusik menambahkan lagu-lagu pop rohani. Untuk Para pemain musik baik alat musik tradisional dan alat musik modern, dituntut untuk bermain menggunakan feeling dikarenakan tidak adanya partitur yang lengkap untuk masing-masing alat musik tradisional dan alat musik modern.

Kendala yang dihadapi para pemain dalam mengiringi ibadah adalah, kurangnya kekompakan dan kerjasama diantara para pemain, pemain yang tidak datang pada saat latihan, sehingga hal ini berpengaruh pada saat mengiringi ibadah, pada saat membaca notasi musik ada sebagian pemain yang sulit untuk menentukan tempo dan nilai not.

Reaksi jemaat muda/i jemaat HKBP Tanjung Sari yaitu Mr. Ivan, Mrs. Debbie dan Mrs. Lolo juga kedua Orangtua jemaat HKBP Tanjung Sari yaitu Bapak Simanjuntak dan Ibu Pangaribuan tentang kolaborasi alat musik tradisional dan alat musik modern dalam mengiringi Ibadah Minggu di HKBP Tanjung Sari Medan adalah diawal masuknya musik tradisional jemaat antusias menerima hal baru terutama dalam hal ini orangtua yang sangat merindukan tradisi begitu pun dengan muda-mudi gereja, akan tetap muda-mudi mulai berkurang pada saat ibadah pagi karena kolaborasi alat musik tersebut yang dimainkan terdengar ricuh, lebih menyenangi ibadah sore dengan iringan musik modernnya.

Saat kebaktian pada hari Minggu pagi digereja HKBP Tanjung Sari Medan, jemaat bersamasama menelaah dan mendengarkan Firman Tuhan supaya mereka diperlengkapi untuk hidup bersama. Bersama-sama mereka bernyanyi memuji Allah, sebagai tanda ucapan syukur atas 
DOI: https://doi.org/10.34007/jehss.v1i3.35

anugerah Allah dan bersama-sama berdoa untuk kehidupan mereka sendiri, untuk saudarasaudara, untuk musuh-musuh serta untuk dunia ini dengan suka dukanya.

Musik di dalam kehidupan jemaat HKBP Tanjung Sari Medan digunakan di dalam berbagai kegiatan. Penggunaan yang utama musik ini adalah di dalam ibadah-ibadah mereka. Di antaranya adalah ibadah hari Minggu, yang di dalamnya mengandung sistem keagamaan yang telah berulang-ulang dilakukan jemaat ini.

Kebaktian Minggu di gereja HKBP Tanjung Sari Medan dibagi atas tiga bagian, yaitu; (1) Ibadah Minggu Pagi masuk pukul 08.00 wib -10.30 wib; (2) Ibadah Minggu Umum masuk pukul 10.30 wib-12.30 wib; dan (3) Ibadah Minggu Sore masuk pukul 17.00 wib -19.00 wib

Ibadah Minggu Pagi menggunakan kolaborasi alat musik tradisional dan alat musik modern dengan lagu nyanyian dari pop rohani popular dan buku Kidung Jemaat. Pengkolaborasian alat musik tradisional dan alat musik modern dalam ibadah minggu pagi dilatar belakangi perkembangan musik ibadah tetangga, kerinduan orangtua akan alat musik tradisional yang semakin dilupakan dijaman sekarang ini dan juga perkembangan musik pop rohani dikalangan masyarakat luas. Dari hasil wawancara penulis dengan Pdt. Ressort HKBP Tanjung Sari Medan Bapak Pdt. Maulinus U.W. Siregar, S.Th, mengatakan bahwa Pengkolaborasian alat musik tradisional dan alat musik modern dalam ibadah minggu pagi ini mulai digunakan sekitar kirakira 2 tahun yang lalu. Salah satu faktor utama diadakannya alat musik tradisional dan alat musik modern dalam minggu pagi adalah untuk memberikan efek sosiologis bahwa jemaat gereja HKBP Tanjung Sari Medan bisa menyuguhkan musik dalam ibadah sesuai dengan perkembangan jaman. Dengan pengkolaborasian alat musik tradisional dan alat musik modern, para jemaat secara khusus bagi kaum muda/i dapat bernyanyi lebih hidup. Mereka tidak lagi mencari alternatif ibadah digereja lain sebab ekspresi musik mereka dalam ibadah sudah terakomodir digereja sendiri.

Berikut adalah rangkaian ibadah minggu pagi tanggal 30 Juli 2017: sebelum acara dimulai terlebih dahulu para pelayan gereja dan penetua gereja berkumpul di konsistori dan berdoa. Setelah itu, mereka memasuki gereja dan menempati posisi masing-msing sesuai dengan tugas pelayanan pada hari itu. Liturgis kemudian mengajak seluruh jemaat untuk saat teduh yang diiringi oleh musik. Setelah saat teduh dilanjutkan dengan pujian "Suci, Suci, Suci" dan Votum. Bagian berikutnya adalah melantunkan lagu pujian berjudul "Kudengar BerkatMu Turun" dan pembacaan Hukum Tuhan. Setelah itu dilanjutkan dengan kembali mengangkat pujian dengan judul lagu "Sungguh Lembut Tuhan Yeseu Memanggil" dan Pengakuan Dosa. Bagian berikutnya adalah Pujian dengan judul "Yang Mahakasih" dan Pembacaan Epistel. Setelah Epistel kemudian mengangkat pujian dengan judul lagu "Kudaki Jalan Mulia" dan Pengakuan Iman. Setelah itu adalah koor NHKBP dan dilanjutkan dengan pembacaan warta jemaat dan doa syafaat. Tata acara ketiga belas adalah mengangkat pujian dengan judul "Kusuka Menuturkan" (sekaligus dengan kolekte/pengumpulan persembahan Ia dan Ib). Acara kemudian dilanjutkan dengan Khotbah oleh Pdt. Marhehe S. Pasaribu, S.Th dengan nats dari 1 Raja-Raja 3: 4-12. Setelah khotbah selesai kemudian ditutup dengan doa dan dilanjutkan mengangkat pujian dengan judul "Berkumandang Suara dari Seberang" (Persembahan II) dan acara ditutup dengan doa Pengutusan dari Bapak Pendeta.

\section{SIMPULAN}

Penggunaan alat musik di gereja HKBP Tanjung Sari Medan dapat dilihat dalam ibadah yang dilakukan. Untuk ibadah Minggu pagi menggunakan Alat musik Tradisional yang dikolaborasikan dengan Alat musik Modern. Ibadah Minggu siang menggunakan Alat musik Modern dan Ibadah minggu sore juga hanya menggunakan Alat musik Modern sebagai musik pengiring ibadah. Gereja HKBP Tanjung Sari Medan menggunakan Alat musik Tradisional yang dikolaborasikan dengan Alat musik Modern dalam mengiringi ibadah setiap Minggu pagi. Pada awalnya Alat musik Tradisional yang dikolaborasikan dengan Alat musik Modern terbentuk karena adanya kerinduan para orangtua akan alat musik tradisional yang semakin dilupakan di jaman sekarang ini. Kendala yang dihadapi para pemain dalam mengiringi ibadah adalah, kurangnya kekompakan dan kerjasama diantara para pemain, pemain yang tidak datang pada 
saat latihan, sehingga hal ini berpengaruh pada saat mengiringi ibadah, pada saat membaca notasi musik ada sebagian pemain yang sulit untuk menentukan tempo dan nilai not.

\section{DAFTAR PUSTAKA}

Bungin, B. (2007). Penelitian Kualitatif.Jakarta: Kencana

Dahana, S.H. (2000). Landasan Program Perencanaan dan Perancangan Arsitektur Pusat Kolaborasi Seni Kontemporer di Yogyakarta. Semarang: Universitas Diponegoro Semarang.

Fathoni, M. (2012). Pengenalan Alat Musik Gamelan Berbasis Multimedia.Jurnal Teknik Informatika. Malang: Universitas Muhammadiyah

Fitrianti, D. (2013). Mengembangkan Kegiatan Gerak dan Lagu untuk Meningkatkan Kemampuan Motorik Kasar pada Anak Usia 5-6 Tahun. Surabaya: Universitas Negeri Surabaya

Hardy, S.J. (2015). Band sebagai Musik Pengiring Ibadah di Gereja Baptis Indonesia Ngadinegaran Yogyakarta. Yogyakarta: Institut Seni Indonesia.

http://anaktebidah.blogspot.com/2012/03/alat-musik-tradisional-nusantara.html

Hutajulu, R. \& Harahap, I. (2005). Gondang Batak Toba I. Bandung: P4ST UPI

Jubelando O. (2009). Musik Gondang Batak Toba sebagai Musik Gerejawi dalam Perwujudan Liturgi Ibadah Gereja HKBP. Medan: Universitas Negeri Medan.Maryeani.2005.Metode Penelitian Kebudayaan, Jakarta: Bumi Aksara.

Manurung, N. (2015). Bentuk dan Fungsi Musik Gondang Sabangunan Batak Toba Pada Grup Horas Rapolo Musik di Semarang. Semarang: Universitas Negeri Semarang.

Pasaribu, M. (2011). Peranan Musik Dalam Proses Pembelajaran Berhitung Pada Anak TK di Taman KanakKanak Negeri 2 Martubung Medan.Medan: Universitas Negeri Medan

Pasaribu, R. (2010). Pemanfaatan Media Pembelajaran Audio Visual Dalam Proses Belajar Mengajar Seni Musik di Kelas XII IPA SMA LET.JEN.S.Parman Medan T.A 2009/2010.Medan: Universitas Negeri Medan

Prier, K.E. (1999). Inkulturasi Musik Liturgi. Yogyakarta: Pusat Musik.

Purba, M. (2005). From Conflict to Reconciliation: The Case of the Gondang Sabangunan in the Order of Discipline of the Toba Batak Protestant Church. Singapore: The National University of Singapore

Salim, P. (1991). Kamus Besar Bahasa Indonesia. Jakarta: Balai Pustaka.

Sedyawati, E. (1992). Pertumbuhan Seni Pertunjukan. Jakarta: Sinar Harapan.

Silitonga. P.H.D., (2017). Ansambel Musik Batak Toba Sebagai Pengiring dalam Peribadatan di Gereja, Gondang: Jurnal Seni dan Budaya, 1 (2): 70-77.

Simbolon, M. (2014). Bentuk Penyajian Musik Gondang Sabangunan sebagai Pengiring Tortor Pada Pesta Adat Tugu Silahisabungan di Desa Silalahi Nabolak Kecamatan Silahi sabungan Kabupaten Dairi. Medan: Universitas Negeri Medan

Soeharto. (2001). Musik Dalam Mencerdaskan Anak. Jakarta: Cakrawala.

Sugiyono, 2015. Metode Penelitian Kuantitatif dan Kualitatif, Bandung: Alfabeta.Tambunan,

Sugiyono, 2009. Metode Penelitian Kuantitatif dan Kualitatif, Bandung: Alfabeta.

Sugiyono. (2008). Metode Penelitian Kuantitatif dan Kualitatif, Bandung: Alfabeta.

Sukardi. (2003). Metodologi Penelitian Kependidikan. Jakarta: Bumi Aksara.

Tahir, M. (2011). Pengantar Metodologi Penelitian Pendidikan. Makassar: Universitas Muhammadiyah Makassar.

Yusuf, M. (2017). Perubahan, Kontinuitas, Struktur Musik, Dan Teks Realisasi Nyanyian Buku Ende dan Kidung Jemaat Yamuger. Gondang:Jurnal Seni dan Budaya, 1 (1): 40-48.

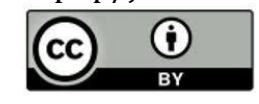

